\title{
Cytological ontogeny of the digestive gland in post-hatching Octopus maya, and cytological background of digestion in juveniles
}

\author{
Rosario Martínez $^{1,2}$, Estefany López-Ripoll ${ }^{3}$, Omar Hernando Avila-Poveda ${ }^{4,5}$, \\ Ronald Santos-Ricalde ${ }^{6}$, Maite Mascaró ${ }^{4}$, Carlos Rosas ${ }^{4, *}$ \\ ${ }^{1}$ Posgrado Institucional en Ciencias Agropecuarias y Manejo de Recursos Naturales Tropicales, \\ Campus de Ciencias Biológicas y Agropecuarias, Universidad Autónoma de Yucatán (UADY), Merida, Yucatan, Mexico \\ ${ }^{2}$ Universidad Intercultural Maya de Quintana Roo (UIMQRoo), Carretera Muna-Felipe Carrillo Puerto km 137 s/n Presumida, \\ Quintana Roo, Mexico \\ ${ }^{3}$ Facultad de Biología Marina, Universidad de Bogotá Jorge Tadeo Lozano (UJTL), Cra. 2 No 11 - 68 Edificio Mundo Marino, \\ El Rodadero, Santa Marta, Colombia \\ ${ }^{4}$ Unidad Multidisciplinaria de Docencia e Investigación (UMDI), Facultad de Ciencias, \\ Universidad Nacional Autónoma de México (UNAM), Puerto de abrigo S/N Sisal, Yucatan, Mexico \\ ${ }^{5}$ Instituto de Industrias, Universidad del Mar (UMAR), Campus Puerto Angel, Distrito de San Pedro Pochutla, Puerto Angel, \\ Oaxaca, Mexico \\ ${ }^{6}$ Departamento de Nutrición Animal, Facultad de Medicina Veterinaria y Zootecnia (FMVZ), \\ Campus de Ciencias Biológicas y Agropecuarias, Universidad Autónoma de Yucatán (UADY), Merida, Yucatan, Mexico
}

\begin{abstract}
The cephalopod digestive gland (DG) is responsible for enzyme production as well as nutrient and lipid storage. Octopus maya (Mollusca: Cephalopoda) is a holobenthic octopus species with aquaculture potential. To develop a balanced food for the rearing of this octopus, it is necessary to understand its digestive physiology. We performed histological studies on the structural change of the DG (cytological ontogeny) associated with age (from 0 to $30 \mathrm{~d}$ posthatching, DPH) and food (postprandial change in 120 DPH juveniles). Early ontogeny of DG was defined in 3 stages: (1) yolk platelets stage ( 0 to $5 \mathrm{DPH})$, (2) transition stage ( 6 to $10 \mathrm{DPH}$ ) and (3) heterolysosomes (food reserves) stage (>12 DPH). In Stage 1, the DG had anatomically undifferentiated tubules, but was filled with yolk platelets. The tubular structures developed lumen by $5 \mathrm{DPH}$. Stage 2 (starting at $6 \mathrm{DPH}$ ) corresponds to mixed exogenous and endogenous feeding. At that time, the yolk platelets were gradually consumed until completely exhausted at 9 DPH. At the onset of Stage 3, the DG structure was completely tubular, exhibiting digestive cell microvilli and other cellular features typical to octupus DGs. During exogenous feeding (12 DPH and onward), acidophilic secretory lysosomes, heterolysosomes and some heterophagosomes appeared on DG cells. O. maya has long digestive cycles in which the extracellular and intracellular digestion can take up to $8 \mathrm{~h}$. Although the ecological implications of this information for aquaculture will still have to be proven, results demonstrated that $O$. maya is an energetically efficient species and thus suitable for rearing in captivity.
\end{abstract}

KEY WORDS: Octopus maya $\cdot$ Days posthatching $\cdot$ Digestive gland $\cdot$ Histology $\cdot$ Postprandial Yolk platelet $\cdot$ Cytology

Resale or republication not permitted without written consent of the publisher

\section{INTRODUCTION}

The digestive gland (DG) of a cephalopod has an important role in its digestive processes, such as enzyme production and nutrient and lipid storage; the latter function is an adaptive response to a particular environment. Octopus maya is a holobenthic octopus species with aquaculture potential that produces large well-developed benthic hatchlings characterized by the presence of adult-like forms. Previous studies have 
demonstrated that to develop a balanced food for rearing cephalopods, it is necessary to know the digestive physiology and the way in which the food is consumed, transformed, absorbed and assimilated (Arvy 1960, Mangold \& Young 1998). Some morpho-physiological features of the DG have been studied in O. maya, such as the digestive enzyme activity (Aguila et al. 2007), the absorption of the inner yolk, which is necessary for arm elongation (Moguel et al. 2010) and the development phases of the digestive cells with age (LopezRipoll 2010). However, it is still necessary to elucidate many of the steps involved in the digestive processes of these octopuses.

An important aspect of the digestive physiology of octopuses resides in the understanding of the absorption and assimilation mechanisms of the nutrients acquired from food. Within the digestive processes of cephalopods, the DG provides most digestive enzymes (Boucaud-Camou \& Roper 1995, Morote et al. 2005); in addition, it works as an energy storage reserve (Bustamante 1998, Mangold \& Young 1998). The DG is the biggest glandular organ visible from the earliest stages of cephalopod development (Lemaire et al. 1977, Boucaud-Camou \& Boucher-Rodoni 1983).

The DG is covered by a thin muscle layer and connective tissue, and consists of a glandular tubule that opens into the digestive ducts, which are covered with a single-layered cylindrical epithelium with a brush border. The tubular structures are surrounded by a basement membrane made up of fine connective tissue that contains blood sinus, lymphatic and excretory ducts (Budelmann et al. 1997). Each tubule is a functional unit and is made up of digestive cells that show structural changes related to the digestion process. The most visible feature of these cells is the presence of different type of grains or vacuoles, depending on the digestive stage: digestion grains of protein character (secretory lysosomes), absorption vacuoles (heterophagosomes) and excretion vacuoles (residual bodies) (Bidder 1950, Boucaud-Camou 1973, BoucherRodoni 1976, Boucaud-Camou \& Yim 1980).

The histological changes (Arvy 1960, Budelmann et al. 1997) and the activity of digestive enzymes (Morote et al. 2005) in the digestive system, including the DG of cephalopods, provide basic information needed to understand the digestion process. In Sepia officinalis the DG cells change during the digestion cycle (BoucaudCamou 1973, Perrin 2004, Perrin et al. 2004) based on their role as cells producing digestive enzymes (Mangold \& Young 1998) or as recipient cells of enzymes originating from other glands, such as the posterior salivary gland (Morishita 1974, Morishita et al. 1974, 1979), which produces chyme after extracellular digestion. A similar behavior has been observed in Alloteuthis media, A. subulata, Euprymna tasmanica, Loligo forbesi, Octopus vulgaris and Sepioteuthis lessoniana (Bidder 1950, 1957, Semmens 2002, Swift et al. 2005).

Although in Octopus maya this type of study has not been performed, the results from other research on the structural changes of the DG and lipid levels during post-hatch development could indicate the presence of an enzymatic adjustment process, and therefore a digestive process (Moguel et al. 2010). The reduction in the proportion of lipids in the tissues and the increase of predatory capacity reveal that the maturity process helps prepare for the capture and ingestion of nutritionally complex prey (Moguel et al. 2010). A similar behavior has been observed in other holobenthic octopus species (e.g. O. bimaculoides), which show mobilization of lipids and amino acids throughout their post-hatch development (Solorzano et al. 2009).

According to Portmann \& Bidder (1928) and Boletzky (1975), during the transition between post-hatch and juvenile stages in cephalopods, the process of yolk absorption is carried out in the DG, which directly receives these reserves from the inner yolk sac by means of the sanguineous torrent that provides the food. Once in the DG, the nutrients are stored and later transported to the blood. This occurs in Octopus maya hatchlings (Moguel et al. 2010) and in paralarvae of Loligo vulgaris reynaudii (Vidal et al. 2005), in which a reduction of the body lipid content during the process of yolk-reserve absorption is observed. In this process, the DG goes from being a reserve and yolk distribution organ to being the organ responsible for the processing of ingested food (Perrin 2004).

A general histological description (obtained in sampling intervals over a $3 \mathrm{wk}$ period) of DG structural change in Octopus maya hatchlings has recently been published (Moguel et al. 2010). In that study, the period of 10 to $15 \mathrm{~d}$ post-hatch (DPH) was defined as a transition before $O$. maya reached the true juvenile stage. In the immediate post-hatch period, octopuses showed an important lipid metabolism related to the use of yolk. This use of lipids provided an increased probability of survival during the first days when food could be limited, mainly when the octopuses have insufficiently developed arms, which is a critical period for hatchling survival. In that sense, a cytological study of the use of yolk reserves during the post-hatch stage is critical to understanding the adaptation capacity of octopuses during that stage. In addition, Moguel et al. (2010) characterized the juvenile stage of $O$. maya as: (1) benthic behavior, (2) selectivity towards certain crustacean prey over others, (3) an exponential growth phase, (4) arms proportionally larger than the mantle, (5) an external source of nutrients and energy from food, (6) DG cells completely developed with heterophagosomes and heterolysosomes and (7) stable enzymatic activity in the DG. 
From this previous study emerged the need to study in greater detail the cytological ontogeny of the DG (e.g. by sampling over a period of days) during the critical post-hatch stage, to find out how yolk reserves are used and determine the moment at which octopuses start feeding from external food sources. Also, the cytological study of the digestive gland during feeding, over a shorter time period (e.g. hours) of the juvenile stage, will enable us to understand the timing of digestion in a mature digestive system. Based on histological observations that included both qualitative examination and quantitative data, the present study was designed to: (1) determine the cytological ontogeny of the digestive gland of Octopus maya during the first $30 \mathrm{DPH}$ and (2) find out how food modulates digestive gland cellular dynamics during digestion (i.e. during the first $8 \mathrm{~h}$ after feeding) of 120 DPH O. maya juveniles.

\section{MATERIALS AND METHODS}

Acquisition and rearing of octopuses. The present study was done at the Experimental Cephalopod Production Unit (EPHAPU) of Unidad Multidisciplinaria de Docencia e Investigación, Universidad Nacional Autónoma de México (UMDI-UNAM), Sisal, Yucatan, Mexico, following the procedures of Rosas et al. (2008), Avila-Poveda et al. (2009) and Moguel et al. (2010) for the collection and maintenance of egg-laying females, as well as for rearing, maintenance, feeding and growth of Octopus maya posthatchlings.

Feeding. All octopuses were fed twice a day at 09:00 and 16:00 $\mathrm{h}$ (at a ration of $30 \% \mathrm{~g}$ wet body weight [wBW]) with semimoist crab paste (95\%) mixed with natural gelatin as an agglutinant (5\%) and placed on empty clam shells (Rosas et al. 2008, Avila-Poveda et al. 2009, Quintana et al. 2010).

Welfare during handling of posthatchlings. Before the octopuses were fixed and the digestive glands were dissected, all octopuses were sedated to induce a total loss of pain sensation by immersing them in seawater at $5^{\circ} \mathrm{C}$ for $3 \mathrm{~min}$ (Roper \& Sweeney 1983) with appropriate consideration to ethics (Mather \& Anderson 2007) and welfare during handling (Moltschaniwskyj et al. 2007).

Cytological ontogeny in the posthatching stage. Cellular changes in the DG during the first $30 \mathrm{DPH}$ were evaluated on a total of 63 Octopus maya (mean \pm SE body weight [BW], $0.14 \pm 0.01 \mathrm{~g}$ ) just hatched from a single egg-laying octopus (Lopez-Ripoll 2010). Three octopuses were sampled daily at random from 0 to $10 \mathrm{DPH}$ and later every $2 \mathrm{~d}$ until reaching $30 \mathrm{DPH}$. Octopuses were fixed in Bouin's solution for $24 \mathrm{~h}$ and preserved in $70 \%$ ethanol with $0.1 \%$ glycerin until histological processing (Bondad-Reantaso et al. 2001, Avila-Poveda \&
Baqueiro-Cardenas 2009). Octopus BW was obtained after fixation according to Avila-Poveda et al. (2009).

Postprandial changes in the juvenile stage. Cellular changes in the DG with postprandial treatment were evaluated on a total of 18 Octopus maya at $120 \mathrm{DPH}$ (mean $\pm \mathrm{SE}$ wBW, $13.98 \pm 3.51 \mathrm{~g}$ ). Octopuses were fasted for $24 \mathrm{~h}$, then allowed to feed for $1 \mathrm{~h}$ on the same food previously provided; afterwards 3 octopuses were randomly selected for the dissection of the digestive gland at different times, starting at $0 \mathrm{~h}$ (i.e. $24 \mathrm{~h}$ fasted), and then at 1, 2, 4, 6 and $8 \mathrm{~h}$ after feeding. A fragment of the DG was fixed and preserved as previously described.

Histological procedures. Samples were washed, dehydrated, cleared and embedded according to AvilaPoveda et al. (2009). Serial sections of $5 \mu \mathrm{m}$ were cut with a manual rotary microtome (model RM 2125, Leica), processed and stained with hematoxylin and erythrosin (Bonet \& Huguet 1985) as well as with the modified Crossmon's trichrome method (i.e. Groat's hematoxylin, erythrosin B-Orange G and trypan blue; Crossmon 1937, Gray 1954) to reveal cytoplasmic granules, reserves, vacuoles and cellular cytoplasm.

Terminology. The terms used, as well as the identification of all the cellular structures and their products (i.e. yolk platelets, boules, absorption vacuoles, shiny food reserves and brown bodies) were based on the definitions given by Boletzky (1975), Boucaud-Camou \& Yim (1980), Semmens et al. (1995), Budelmann et al. (1997), Westermann \& Schipp (1998a,b), Semmens (2002), Perrin (2004) and Swift et al. (2005). In the present study, terms were updated and replaced according to the type of digestive bodies (lysosomes), which made it easier to follow the process of intracellular digestion and its timing (Sastry et al. 2004): 'boules' became secretory lysosomes, 'absorption vacuoles' became heterophagosomes, 'shiny food reserves or lipid droplets' became heterolysosomes, and 'brown bodies' became residual bodies.

Quantitative measurements. For the structural change of the digestive gland (i.e. cytological ontogeny) the following measurements on each individual were performed: yolk platelets height $(\mathrm{YPH}, \mu \mathrm{m})$, yolk platelets surface density (YPsD, no. $\mathrm{mm}^{-2}$ ) and the heterolysosomes diameter (HLDi, $\mu \mathrm{m})$. Changes in the DG during the transition from posthatching to the juvenile stage of Octopus maya were taken into account.

For the digestive rhythms of the DG (i.e. postprandial changes), the following measurements on each individual were performed: secretory lysosomes diameter (SLDi, $\mu \mathrm{m})$, secretory lysosomes surface density (SLsD, no. $\mathrm{mm}^{-2}$ ), heterophagosomes diameter (HPDi, $\left.\mu \mathrm{m}\right)$, heterophagosomes surface density (HPsD, no. $\mathrm{mm}^{-2}$ ), heterolysosomes surface density (HLsD, no. $\mathrm{mm}^{-2}$ ) and residual bodies surface density ( $\mathrm{RBsD}, \mathrm{no} . \mathrm{mm}^{-2}$ ). 
Microscopy examinations. Observations, structures of cells (i.e. YPH, YPsD, HLDi, SLDi, SLsD, HPDi, HPsD, HLsD, RBsD) and digital images of the digestive gland were achieved with a digital imaging system (DS-5M-L1 Digital Sight Camera System, Nikon) mounted on a microscope (Eclipse ME-600, Nikon). The digestive glands were divided by means of a digital graticule drawn by means of the previous camera system to establish the scale in microscopic rectangular quadrats (Q) with dimensions of $0.116 \times 0.155 \mathrm{~mm}$ and area of $0.018 \mathrm{~mm}^{2}$. All the structures of cells were measured on randomly selected individuals at $400 \times$ magnification within 6 of the measured quadrats. Total relative surface area measured was then considered as $0.108 \mathrm{~mm}^{2}$ (sum of area for 6 quadrats [ $\left.\Sigma \mathrm{Q}\right]$ ) (Fig. 1). The quadrats were randomly selected using the method of the accumulated average (Gotelli \& Ellison 2004). Surface density (Sd: number [N] of each cell structure $[\mathrm{cs}] \mathrm{mm}^{-2}$ ) was then estimated according to Mayhew (1979) as:

$$
\mathrm{Sd}=\Sigma \mathrm{NCS}_{\mathrm{C}} / \Sigma \mathrm{Q}
$$

Statistical analysis. Data were expressed as mean \pm SE. Differences among values of each measurement variable (i.e. SL, HP, HL and RB) for cytological and postprandial changes throughout time were analyzed by a nested ANOVA (values of each measurement variable nested within quadrats and the quadrats nested within the digestive glands) followed by Duncan's multicomparison test (Gotelli \& Ellison 2004) through the generalized linear model (GLM). Tests

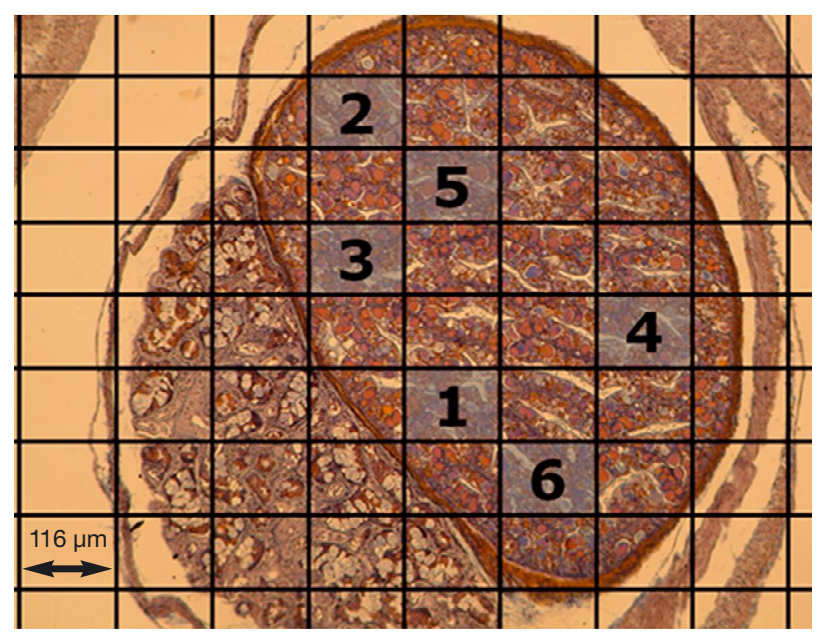

Fig. 1. Octopus maya. General schematic of the quantitative method showing the 6 quadrats randomly selected for the digestive gland. Each quadrat is a rectangle $0.116 \mathrm{~mm} \times$ $0.155 \mathrm{~mm}$ in size with a surface area of $0.018 \mathrm{~mm}^{2}$ (total surface area measured: $0.018 \mathrm{~mm}^{2} \times 6=0.108 \mathrm{~mm}^{2}$ ). Yolk platelets, heterolysosomes, secretory lysosomes, heterophagosomes and residual bodies were counted in each quadrat at $400 \times$ magnification were carried out to determine homogeneity of variances for all measurements. Those that did not fit the premises for ANOVA were transformed using more appropriate measurement scales. Statistical analysis was carried out with the computer program STATISTICA 6. Statistical significance was accepted at $\mathrm{p}<0.05$.

\section{RESULTS}

\section{Cytological changes through ontogeny: histology}

Three developmental stages of the digestive gland of Octopus maya were observed and were determined according to the progressive disappearance of the yolk platelets compared with the progressive appearance of heterolysosomes and heterophagosomes, as well as that of the secretory lysosomes and residual bodies. In addition, the progressive structural and functional establishment of the digestive cells (morphogenesis) that will form each tubule of the gland was analyzed. The first stage, showing only yolk platelets, was observed in octopuses of ages between 0 and $5 \mathrm{DPH}_{\text {; the second }}$ stage, showing the transition from yolk platelets to heterolysosomes, was observed in ages 6 to $10 \mathrm{DPH}$, and the third stage, showing no yolk platelets, was observed in octopuses older than 12 DPH (Fig. 2).

At $0 \mathrm{DPH}$, we only observed numerous large formless yolk platelets within a digestive gland in early diverticular morphogenesis with anatomically undifferentiated tubules. The presently undefined basement membrane showed the yolk platelets contained in each undifferentiated tubule. Undifferentiated tubules were clearly separated from each other by this basement membrane. The undefined lumen of the undifferentiated tubules also started to appear (Fig. 2A).

A gradual reduction of the YPH, as well as a beginning of tubules shaping with lumen was observed as the age of octopuses increased (Fig. 2B,C). The digestive cells showed distinguishable subcellular organization after $5 \mathrm{DPH}$ once a tubular organization pattern was observed in the digestive gland (Fig. 2D). The digestive gland from this age onward was more intensively permeated (soaked) by a fluid stained blue (indicating acid), according to the Crossmon's trichrome stain used in this study (Fig. 2D-F).

From 6 to $9 \mathrm{DPH}$, the tubular structure became more evident and the cells showed a brush border (i.e. microvilli) on the apical membrane that faces the lumen, indicating the start of development to the juvenile stage. The presence of acidophilic chyme in the lumen indicates that these octopuses began to ingest food causing lumen distension. At this time the yolk platelet was gradually consumed until completely ex- 


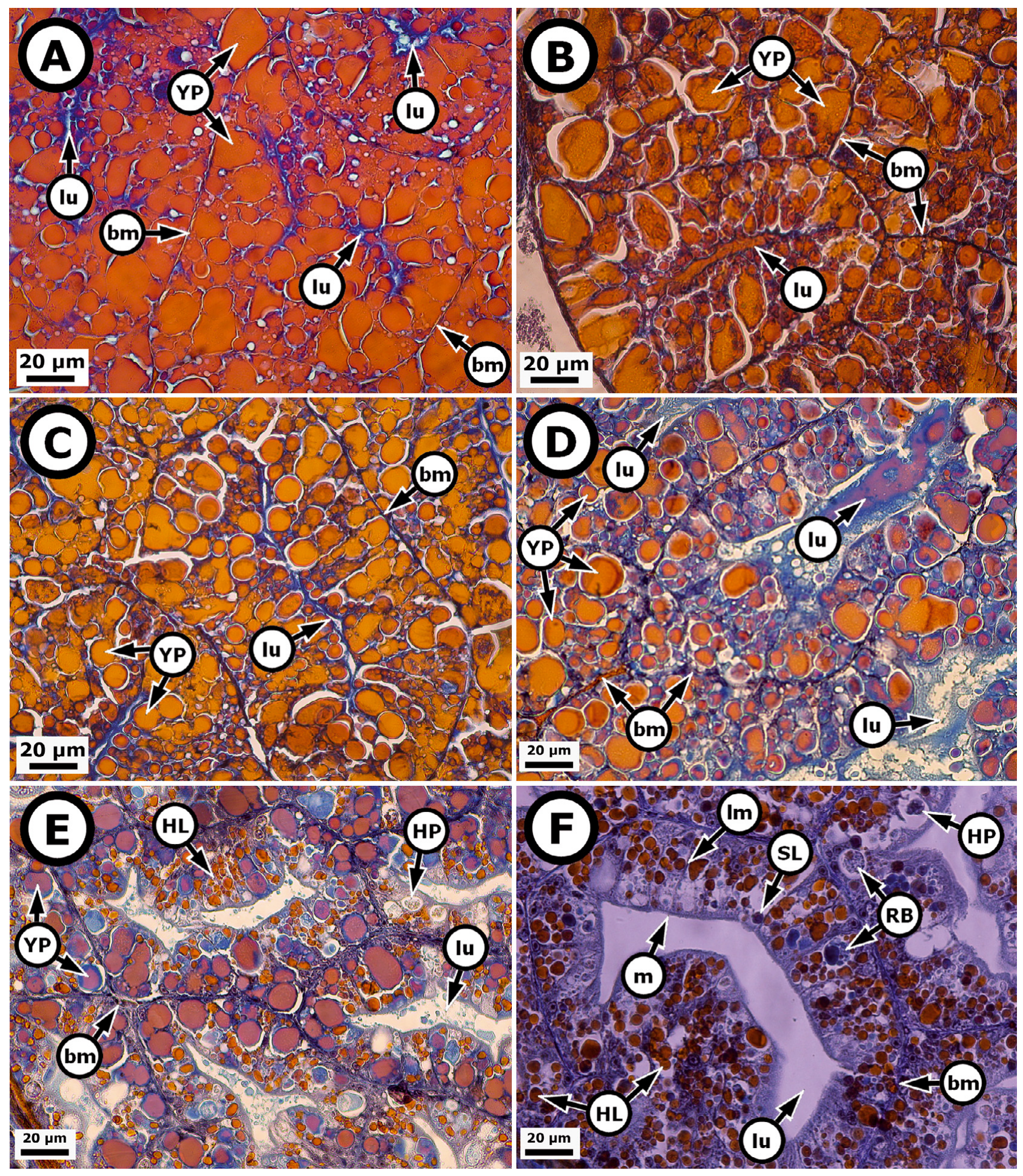

Fig. 2. Octopus maya. Early cytological ontogeny of the digestive gland at 6 different d posthatching (DPH) showing the structural changes throughout the 3 developmental stages. Micrographs at (A) 0 DPH showing the digestive gland in early diverticular morphogenesis with anatomically undifferentiated tubules that are completely filled with yolk platelets, (B) 1 DPH and (C) 2 DPH showing the tubules beginning to form in the digestive gland with a subcellular organization, (D) 5 DPH showing the digestive gland with more distinguishable subcellular organization and a more defined pattern of differentiated tubular organization, (E) 7 DPH showing the tubular structure with definite cellular organization; the distension of the lumen with chyme indicates that octopuses had begun to ingest food, and (F) 22 DPH showing a distinct digestive cell with microvilli forming completely developed tubules; in this case the DG is fully formed. bm: basement membrane; HL: heterolysosomes; HP: heterophagosomes; lm: lateral membrane; lu: lumen; m: microvilli; RB; residual bodies; SL, secretory lysosomes; YP: yolk platelets 
hausted at $9 \mathrm{DPH}$, at the same time that the heterolysosomes and the heterophagosomes were gradually appearing (Fig. 2E).

From 10 DPH onward glandular development was complete in the tubules and digestive mature cells were anchored to the basement membrane. The lateral membrane separating the cells that make up each tubule was conspicuous. Microvilli on the apical membrane were more prominent as were the heterophagosomes. At this time, acidophilic secretory lysosomes appeared for the first time, and some residual bodies, formed by a fusion of secretory lysosomes and heterolysosomes, could be observed. Heterolysosomes were bigger than they were during the previous transition stage. Again, an acidophilic fluid permeating all of the digestive gland became more conspicuous than was evident during the previous days (Fig. 2F).

\section{Cytological changes through ontogeny: morphometry}

During the yolk platelet stage, changes with age were observed in the YPH of octopuses between 1 and 5 DPH. A maximum YPH value was observed at $1 \mathrm{DPH}$ and a minimum at $5 \mathrm{DPH}(\mathrm{p}<0.05)$. During the transition stage, YPH was reduced, reaching the lowest value at 8 DPH $(p<0.05$; Fig. 3A). During the yolk platelet stage, a lack of uniformity of YPsD was observed until $6 \mathrm{DPH}$, and densities fluctuated between 1000 and 2000 yolk platelets $\mathrm{mm}^{-2}$. Thereafter, during the transition stage, a dramatic reduction in YPsD was observed and values ranged between 100 and 500 yolk platelets $\mathrm{mm}^{-2}$ at 7 and $8 \mathrm{DPH}(\mathrm{p}<0.05$ Fig. 3B). After $9 \mathrm{DPH}$, yolk platelets had completely disappeared.

The HLDi values appeared during the transition stage for the first time at around 6 DPH and showed a

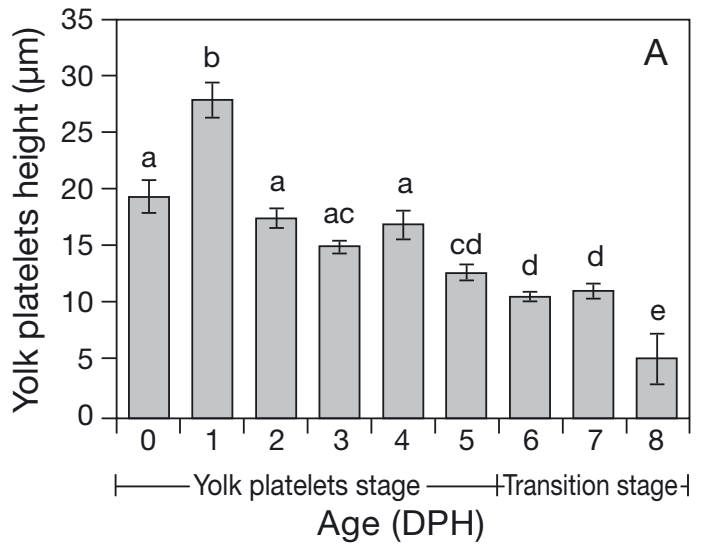

significant reduction until $10 \mathrm{DPH}$. Subsequently, from $12 \mathrm{DPH}$ to $30 \mathrm{DPH}$ the HLDi increased irregularly with age. The highest values $(7.18 \pm 0.25 \mu \mathrm{m})$ were found in octopuses at 12, 16, 22 and $28 \mathrm{DPH}$ and the lowest $(3.20 \pm 1.60 \mu \mathrm{m})$ in octopuses at $24 \mathrm{DPH}$ (Fig. 4).

\section{Postprandial changes assessed through histology}

At $0 \mathrm{~h}$ of the postprandial period (i.e. octopuses fasted for $24 \mathrm{~h}$ ), resting cells were observed. Cells appeared to have few or no heterolysosomes or residual bodies. An apocrine secretion and cell debris inside the tubular lumen were also observed, which resulted from autophagy in response to food deprivation for 24 h (Fig. 5A).

During the 1 and $2 \mathrm{~h}$ of the postprandial period (PP), digestive cells showed nuclei forming a belt at the bottom of each columnar cell as the typical characteristic. Some heterolysosomes appeared inside the digestive cells. Few tubules showed acidophilic chyme in the lumen (Fig. 5B).

At $4 \mathrm{~h}$ PP, the digestive cells were storing heterolysosomes (nutrients). In addition, heterophagosomes were observed only near the apical zone of the cell, revealing the beginning of nutrient transport. Digestive cells showed a brush border (i.e. microvilli) on the apical membrane that faced the lumen. Acidophilic chyme was observed in the center of the lumen. Neither secretory lysosomes nor residual bodies were observed (Fig. 5C).

At $6 \mathrm{~h} \mathrm{PP}$, the digestive cells showed a conspicuous brush border (microvilli) and an empty lumen. Digestive cells were filled with heterolysosomes, without heterophagosomes (Fig. 5D).

At $8 \mathrm{~h} \mathrm{PP}$, a reduction in heterolysosomes was observed. Residual bodies, cell debris and apocrine se-

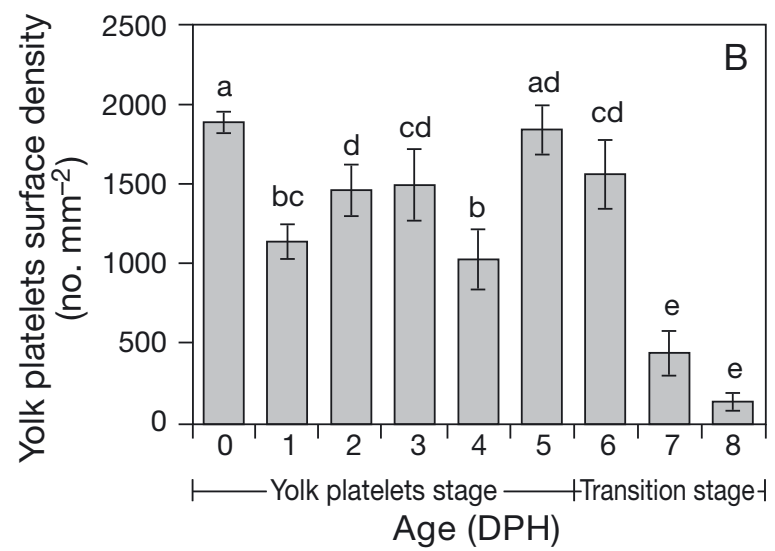

Fig. 3. Octopus maya. Morphological changes of the yolk platelets in the digestive gland during the first $8 \mathrm{~d}$ posthatching (DPH). (A) Yolk platelet height. (B) Yolk platelet surface density. Values are mean \pm SE. Different letters indicate significant differences among values at $p<0.05$. Respective digestive gland developmental stages indicated by age. Total number of microscopic observations for each time point $\left(\mathrm{DPH}, \mathrm{N}_{\mathrm{DPH}}=18\right.$ ) was determined in 6 quadrats in each of 3 digestive glands 


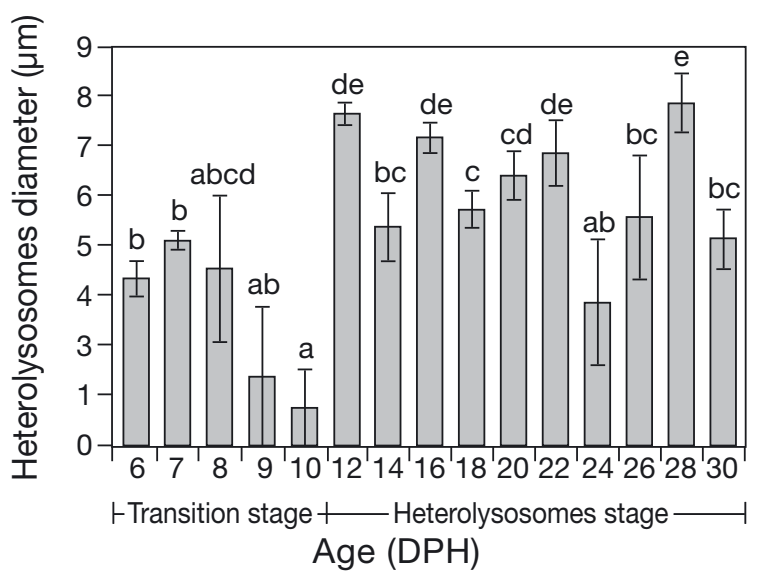

Fig. 4. Octopus maya. Morphological changes in the diameter of heterolysosomes in the digestive gland from 6 to $30 \mathrm{~d}$ posthatching $(\mathrm{DPH})$. Values are mean \pm SE. Different letters indicate significant differences among values at $\mathrm{p}<0.05$. Respective digestive gland developmental stages indicated by age. Total number of microscopic observations for each time point ( $\left.\mathrm{DPH}, \mathrm{N}_{\mathrm{DPH}}=18\right)$ was determined in 6 quadrats in each of 3 digestive glands

cretion in the lumen was observed for a second time. Again, the proliferation of nuclei indicated the presence of replacement cells located in the basal lamina (Fig. 5E).

\section{Postprandial changes assessed through morphometry}

The SLDi and SLsD did not show significant differences among the PPs, except at $2 \mathrm{~h}$ and $0 \mathrm{~h}$, respectively ( $p>0.05$; Fig. 6).

Heterophagosomes appeared for the first time at $2 \mathrm{~h}$ $\mathrm{PP}$ and had a tendency to increase in diameter and in number, revealing a significant effect of the feeding period on the HPDi and HPsD (Fig. 7).

A significant effect of feeding was observed in the HLsD with the highest values occurring at $4 \mathrm{~h} \mathrm{PP}(\mathrm{p}<$ $0.05)$. The smallest values were recorded at the beginning $(0,1$ and $2 \mathrm{~h} \mathrm{PP})$ and later at $8 \mathrm{~h}$ PP ( $\mathrm{p}>0.05$; Fig. 8).

The RBsD was affected significantly by the PP and showed a progressive increase from 1 to $6 \mathrm{~h}$ PP (p< 0.05; Fig. 9). At 0 h (i.e. $24 \mathrm{~h}$ fasted), no residual bodies were observed.

\section{DISCUSSION}

This study provides for the first time the description of structural changes (i.e. cytological ontogeny) in the digestive gland of posthatching Octopus maya associated with the age during its early life and with the feeding (postprandial changes) during digestion in its juvenile stage. The digestive gland of $O$. maya changes and goes through several developmental stages during the first days of posthatch (Rosas et al. 2007, Lopez-Ripoll 2010, Moguel et al. 2010). Our results showed 3 digestive characteristics of octopuses after hatching. The first is defined as the yolk platelets stage (0 to $5 \mathrm{DPH})$, the second as the transition stage (6 to $10 \mathrm{DPH}$ and containing a mix of yolk platelets and heterolysosomes) and the third as the heterolysosome stage (12 DPH onward). A similar pattern has been observed in other cephalopod species, such as Sepia officinalis (Yim \& Boucaud-Camou 1980) and Sepioteuthis lessoniana (Semmens 2002), where cephalopods reached their total development several days after hatching (Boucaud-Camou \& Boucher-Rodoni 1983). This is not exclusive to cephalopods; Herrera et al. (2010) proposed and defined 3 stages for the digestive development of sole Dicologoglossa cuneata larvae, according to the feeding category and the timing of ingestion, as well as digested food as: Stage 1 or endotrophic (0 to $1 \mathrm{DPH}$, larvae only fed on vitellus), Stage 2 or mixed feeding (2 to $3 \mathrm{DPH}$, exogenous and endogenous feeding) and Stage 3 or exotrophic (4 to $33 \mathrm{DPH}$, exclusively exogenous feeding with total yolk exhaustion).

Structural change of the digestive gland of Octopus maya was related to age. During the first $5 \mathrm{DPH}_{\text {, the }}$ digestive gland had not yet developed defined cellular and tubular structures, but a basement membrane that demarcated the undifferentiated tubules was present. Similar characteristics were also observed in Sepia officinalis in which the digestive system at the time of hatching was not mature (Boucher-Rodoni et al. 1987). In addition, from 0 to $5 \mathrm{DPH}$ in $O$. maya the structures that dominated the architecture of the digestive gland were the yolk platelets, which are the source of nutrients for the maintenance and development of the embryo and hatchling during the first posthatching days. These large yolk platelets are filled with yolk proteins (vitellin), which are phospho-lipo-glycoproteins derived from a larger maternal precursor, vitellogenin (Vg), which has been extensively studied in several organisms due to its role in reproduction, breeding and digestion (Lee 1991, Matozzo et al. 2008).

Boletzky (1975) observed that, during development, the inner yolk sac is in contact with a large blood sinus, which persists in adult octopods as the sinus mesentericus. The nutrients from the inner yolk sac go directly towards the blood, from there to the digestive gland, where they form yolk platelets, which are later absorbed and distributed by the circulatory system. The inner yolk sac is an independent organ from the digestive gland and is separated from it by connective tissue.

Results obtained in the present study showed a DG with yolk platelet material occupying the cytoplasm of digestive cells in a diffuse way. According to Boletzky (1975) the yolk platelets in the DG are supplied with 


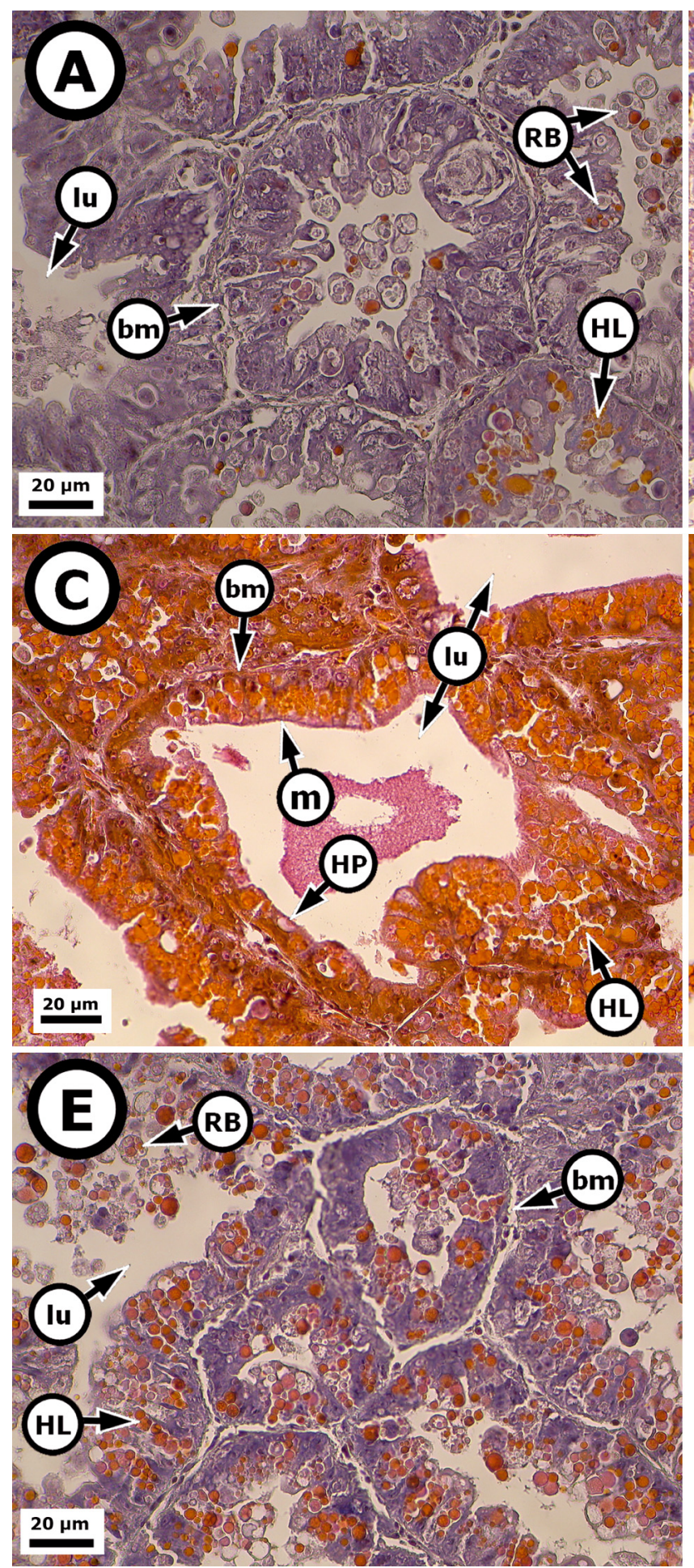

blood carrying nutrients collected from the surface of the inner yolk sac. During the process yolk-derived material would be incorporated into the endolysosomal system (van Meel \& Klumperman 2008) (Fig. 2B) and digested intracellularly either alone (2 to $5 \mathrm{DPH}_{\text {; }}$ Fig. 2C,D) or mixed with external food (5 DPH onward;

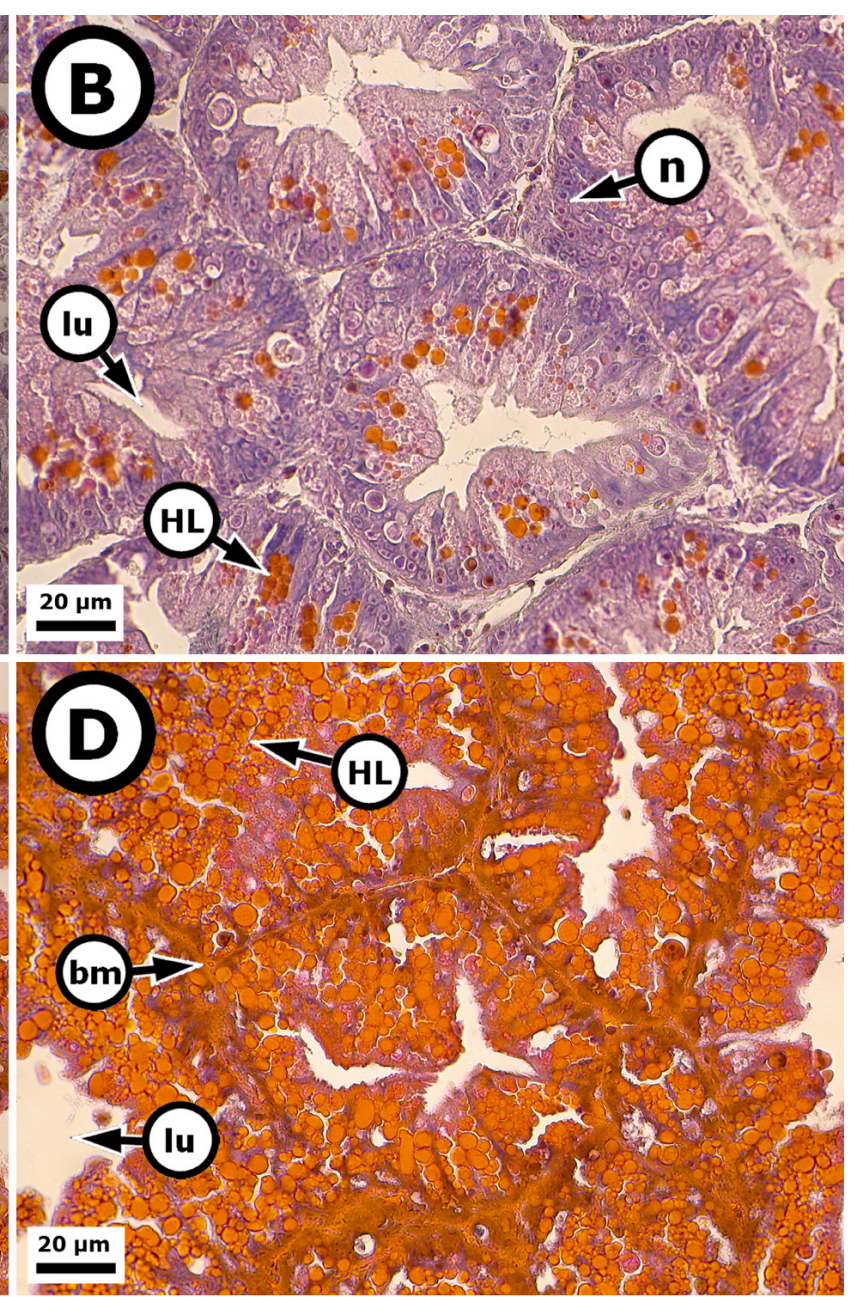

Fig. 5. Octopus maya. Postprandial changes of the digestive gland $120 \mathrm{~d}$ posthatching (DPH). Cellular features at (A) $0 \mathrm{~h}$, i.e. octopuses fasted for $24 \mathrm{~h}$, (B) $1 \mathrm{~h}$ (at $2 \mathrm{~h}$ there was no noticeable change), (C) $4 \mathrm{~h}$, (D) $6 \mathrm{~h}$ and (E) $8 \mathrm{~h}$. bm: basement membrane; HL: heterolysosomes; HP: heterophagosomes; lu: lumen; $\mathrm{m}$ : microvilli; $\mathrm{n}$ : nuclei forming a belt at the bottom; RB: residual bodies

Fig. 2E) until external food is the only energy source (e.g. 22 DPH; Fig. 2F). This has been observed in Eledone cirrosa, E. moschata, Illex coindetii, Loligo vulgaris, Octopus briareus, O. joubini, O. maya, O. salutii, O. vulgaris, Rossia macrosoma, Sepia officinalis, Sepietta obscura and Sepiola robusta (Boletzky 1975). 

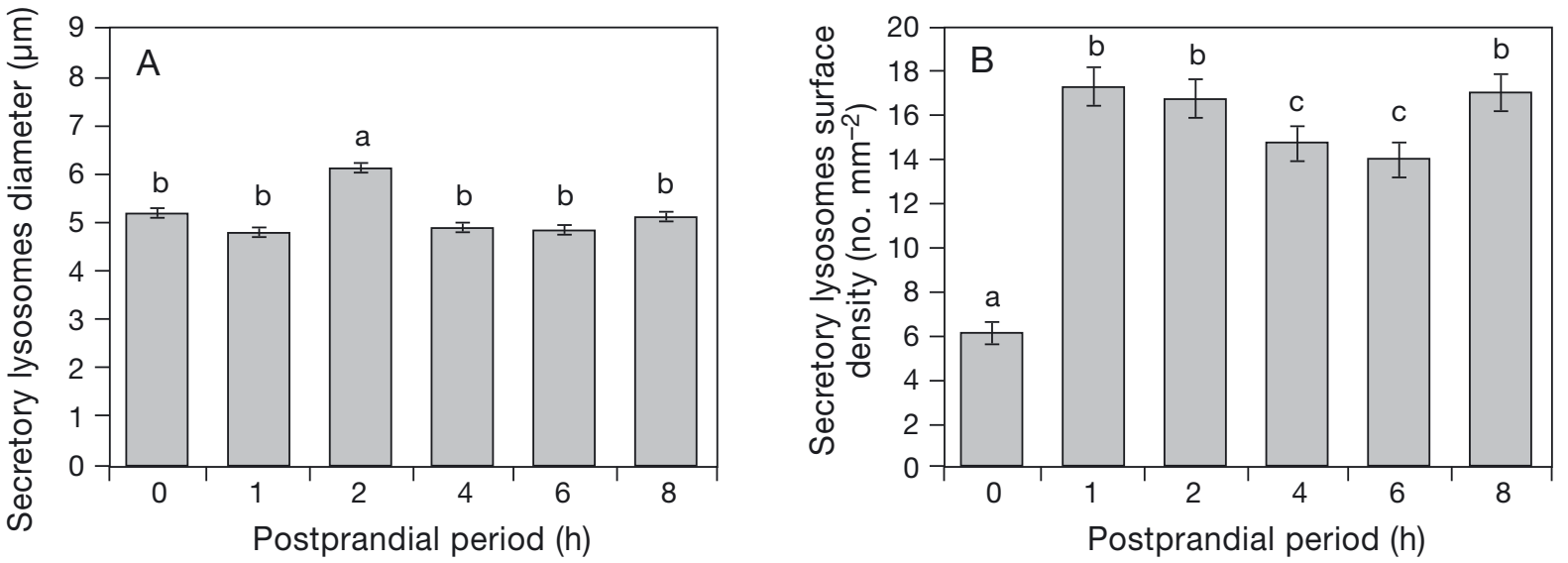

Fig. 6. Octopus maya. Morphological changes of the secretory lysosomes in the digestive gland of juveniles at $120 \mathrm{~d}$ posthatching (DPH) throughout the postprandial period. (A) Diameter of secretory lysosomes. (B) Surface density of secretory lysosomes. Values are mean \pm SE. Different letters indicate significant differences among values at $p<0.05$. Total number of microscopic observations for each hour $\left(\mathrm{N}_{\mathrm{h}}=18\right)$ was determined in 6 quadrats in each of 3 digestive glands
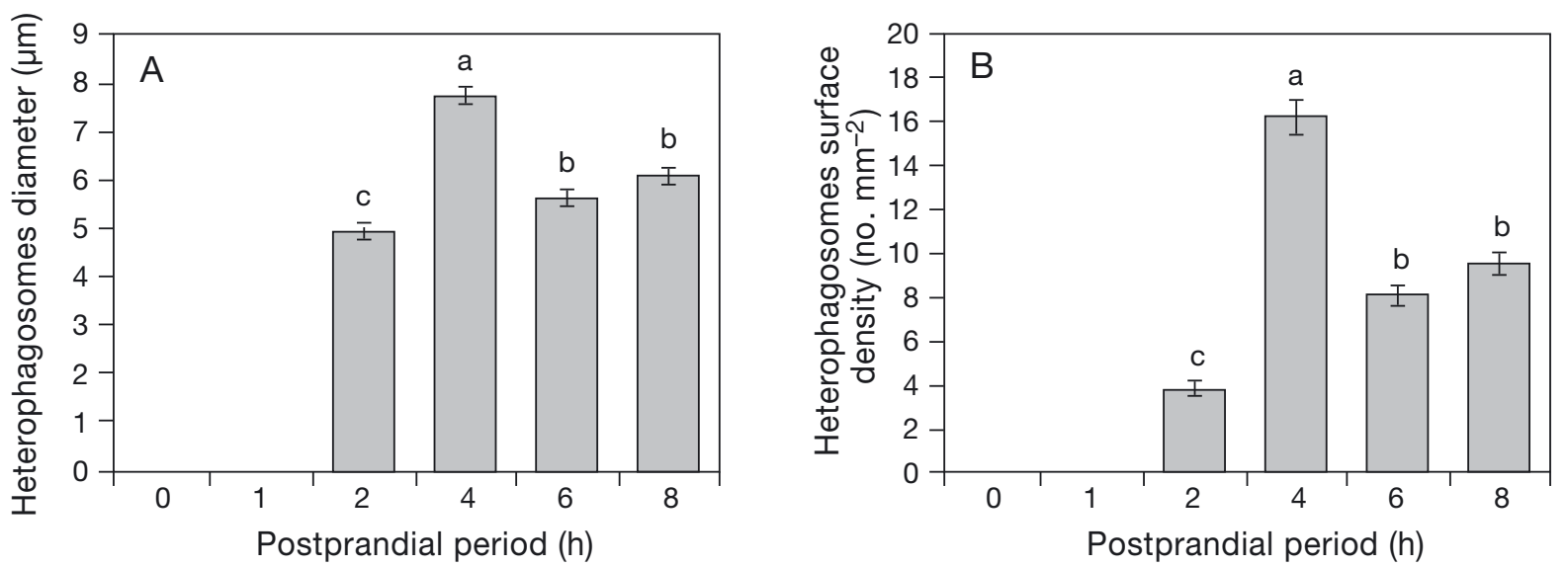

Fig. 7. Octopus maya. Morphological changes of the heterophagosomes in the digestive gland of juveniles at $120 \mathrm{~d}$ posthatching (DPH) throughout the postprandial period. (A) Diameter of heterophagosomes. (B) Surface density of heterophagosomes. Values are mean \pm SE. Different letters indicate significant differences among values at $p<0.05$. Total number of microscopic observations for each hour $\left(\mathrm{N}_{\mathrm{h}}=18\right)$ was determined in 6 quadrats in each of 3 digestive glands

Although the differentiation and maturation of the DG cells follow similar patterns among cephalopods (Yim \& Boucaud-Camou 1980, Boucaud-Camou \& Boucher-Rodoni 1983, Semmens 2002, Perrin 2004) differences have been reported in the digestive capability and the ways cephalopods digest food (Vecchione 1987, Vecchione \& Hand 1989). For example, Perrin (2004) reported the presence of secretory lysosomes (or boules) in the digestive cells of Sepia officinalis as also seen in our study for Octopus maya; whereas, Semmens (2002) noticed the absence of secretory lysosomes (or boules) in Sepioteuthis lessoniana and the presence of smaller secretory grains (i.e. residual bodies) thought to be carriers of digestive enzymes. The variations in YPsD in the digestive gland of $O$. maya throughout the posthatching period could be associated with individual variability within the sampled hatchling population. Variability at hatching is a characteristic that affects the octopus life during the first posthatching days in such a way that it could also affect the individual YPsD, thereby producing the erratic behavior observed in the present study. This variability been recently demonstrated in $O$. maya (Briceño 2009, Briceño et al. 2010a,b, Moguel et al. 2010) and other cephalopods (e.g. O. pallidus, Leporati et al. 2007). Although, we do not know what kind of effect could be related to the different use of yolk platelets, it is possible that different YPsD in organisms of the same age could provoke different growth rates and, in consequence, organisms of different size.

Vidal et al. (2005) found that the lipid droplets (i.e. heterolysosomes) present in the posthatching period of Loligo vulgaris were used as an energy reserve necessary to complete the development in that species. Zero 


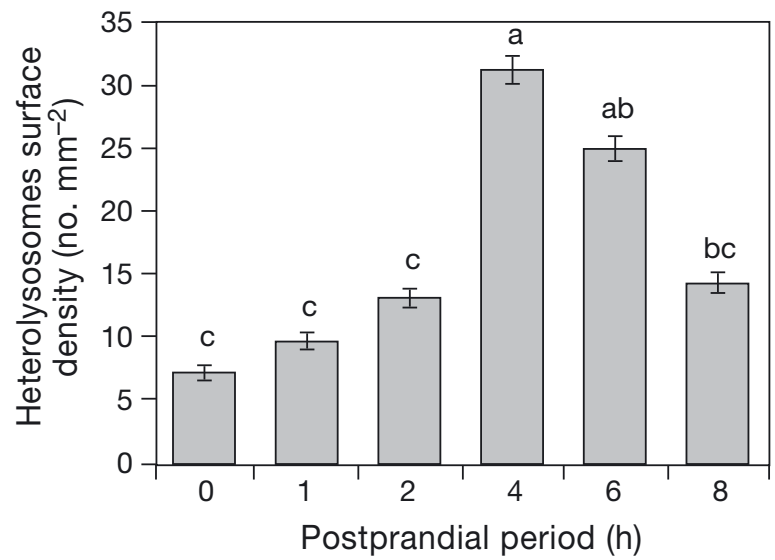

Fig. 8. Octopus maya. Morphological changes of the heterolysosomes surface density in the digestive gland of juveniles at $120 \mathrm{~d}$ posthatching (DPH) throughout the postprandial period. Values are mean \pm SE. Different letters indicate significant differences among values at $\mathrm{p}<0.05$. Total number of microscopic observations for each hour $\left(\mathrm{N}_{\mathrm{h}}=18\right)$ was determined in 6 quadrats in each of 3 digestive glands

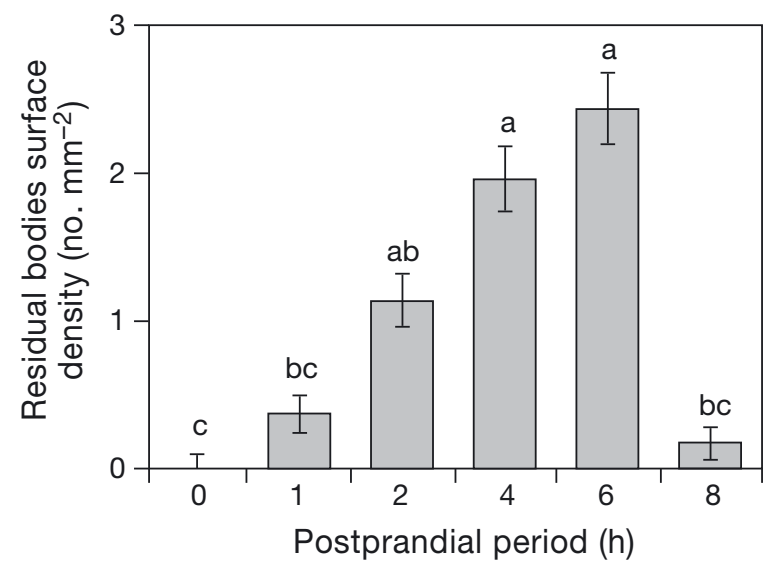

Fig. 9. Octopus maya. Morphological changes of the residual bodies surface density in the digestive gland of at $120 \mathrm{~d}$ posthatching (DPH) throughout the postprandial period. Values are given as means \pm SE. Different letters indicate significant differences among values at $p<0.05$. Total number of microscopic observations for each hour $\left(\mathrm{N}_{\mathrm{h}}=18\right)$ was determined in 6 quadrats in each of 3 digestive glands

growth during this stage also demonstrated that the yolk platelets were not sufficient to satisfy the energy demands for the growth of these organisms.

Combined with the morphologic adjustments, Moguel et al. (2010) observed in Octopus maya a reduction of the dorsal mantle length (DML) in relation with the total length (TL) and an increase in the arm length (AL) relative to TL (i.e. DML:TL ratio and AL:TL ratio, respectively). These observations provide evidence that the reduction of yolk platelets, as observed by us in this study, allow the organism to obtain the energy needed for growth of the arms, which are fundamental tools for feeding.
On the other hand, there is evidence that $\mathrm{pH}$ may be the key regulator of yolk degradation. In a diversity of other species, such as the sea urchin Arbacia punctulata (Armant et al. 1986), the fruit fly Drosophila melanogaster (Medina \& Vallejo 1989), the tick Ornithodoros moubata (Fagotto 1990a,b, 1991) and the frog Xenopus laevis (Fagotto \& Maxfield 1994), yolk proteins were not degraded before late embryogenesis, which implies some regulatory mechanism. In tick eggs, acidic proteinases are stored in the yolk as a latent, acid-activable proenzyme (Fagotto 1990b). The yolk platelets are initially neutral, but they become acidic later in development, causing proenzyme maturation and yolk degradation (Fagotto 1991). Yokota \& Kato (1988) indicated, for sea urchin eggs and embryos, that the degradation of yolk proteins resulted from the incubation of yolk granules in acidic conditions. Umezawa (1982) presented evidence that the most abundant yolk protein is proteolytically processed primarily by the cathepsin-B-like enzyme. Octopus maya probably has this same regulatory enzymatic mechanism for yolk degradation. The acidophilic fluid permeating all the DG at around 5 DPH and coinciding with the beginning of exogenous feeding could be evidence for this enzymatic mechanism, but studies on the participation of acidophilic enzymatic activity in yolk degradation are missing. Furthermore, peaks in digestive enzyme activity in $O$. maya hatchlings during the first $30 \mathrm{DPH}$ (Moguel et al. 2010) coincide well with the decrease in density of yolk platelets and with the cytological changes observed in this study (e.g. at $5 \mathrm{DPH}$ ).

In Sepia officinalis the evolution of the digestive system starts with the first feeding, even when some internal yolk remains (Boucher-Rodoni et al. 1987). Something similar happened in Octopus maya, between 6 and $7 \mathrm{DPH}$, when the subcellular organization pattern of the digestive gland became more evident. After the first feeding, the lumen opened to give way to chyme absorption, suggesting that the stimulation for the cellular differentiation happened at this moment. In addition, digestive enzyme synthesis started when the organism began to digest and absorb nutrients from the consumed food.

Regarding postprandial changes, Octopus maya DG cells changed during the feeding cycle, as was also observed in Sepia officinalis (Boucaud-Camou 1968, 1973, Perrin 2004, Perrin et al. 2004). During this process, the digestive cells changed based on their role, either as digestive enzyme-producing cells or as recipient cells for the produced chyme. A similar pattern has also been observed in Alloteuthis media, A. subulata, Euprymna tasmanica, Loligo forbesi, O. vulgaris and Sepioteuthis lessoniana (Bidder 1950, 1957, Semmens 2002, Swift et al. 2005). In O. maya, as in other cephalopods, the DG cells do not work in synchrony 
and they respond to the presence of food in the digestive tract. This has caused confusion, since during the digestive process DG cells seem to be morphologically different, depending on the time when the animals were sampled, without really being cells of different lineages (Boucaud-Camou \& Yim 1980, BoucaudCamou \& Boucher-Rodoni 1983, Boucher-Rodoni et al. 1987, Semmens 2002). In the present study, we observed the same cellular type in organisms fasted for $24 \mathrm{~h}$, demonstrating that the O. maya DG cells have the same role as that in other cephalopods.

The high SLsD in the DG of Octopus maya indicates that the extracellular digestive enzymes were released during the first hour after having been fed. This process has been observed also in Sepioteuthis lessoniana (Semmens 2002), a species in which the digestive process can take only $4 \mathrm{~h}$. For the chyme processing, the digestive cells of $O$. maya need more time, since at $4 \mathrm{~h}$ PP they are still absorbing and storing nutrients. At this time, the nutrients from the food have not yet been sent to the blood stream, which demonstrates that the internal digestion processes are still developing. Once the intracellular digestion has concluded, $8 \mathrm{~h} \mathrm{PP}$, the cells are ready to initiate a new digestive cycle.

Apparently the relation between the feeding and the production of secretory lysosomes (previously called boules) is a species-specific process. In Euprymna tasmanica, Swift et al. (2005) observed a 6-fold increase in density of secretory lysosomes during the course of digestion, reaching the highest density between 2 and $8 \mathrm{~h}$ after feeding. In Octopus maya, a strong increase in the SLsD was observed $1 \mathrm{~h}$ after feeding; this level stayed constant throughout the entire digestive cycle. The distribution frequency of secretory lysosome sizes in $E$. tasmanica changed after feeding, since relatively larger structures $(>4 \mu \mathrm{m})$ were observed at 0 and $30 \mathrm{~min}$ after feeding. In contrast, in O. maya, either fasted or fed, the SLDi was constant (between 5 and $6 \mu \mathrm{m}$ ), suggesting that not only the amount but also the dimensions of secretory lysosomes are retained throughout digestion. This implies that $O$. maya could be ready for a continuous enzymes production in preparation for feeding. Eledone cirrosa, Idiosepius pygmaeus and O. vulgaris (Boucher-Rodoni 1976, Semmens et al. 1995) release digestive enzymes immediately after feeding, although they also release these enzymes more than once during digestion. The present results suggest that $O$. maya belongs to this group of cephalopods and not to those releasing digestive enzymes a single time during the digestive process, like Illex illecebrosus and Sepioteuthis lessoniana (Boucher-Rodoni 1976, Semmens 2002).

As expected, in Octopus maya the residual bodies are absent during fasting and increase as digestion moves on. A peak in the RBsD was observed in $O$. maya at $6 \mathrm{~h}$ PP indicating that the elimination process of remnants has reached its maximum level. At $8 \mathrm{~h}$ PP, the RBsD was low, indicating that the digestive cycle had finished. A similar, but more accelerated, process has been observed in Sepioteuthis lessoniana (Semmens 2002).

\section{CONCLUSIONS}

The cytological ontogeny of the digestive gland with age shows that Octopus maya juveniles go through a transition process during which embryonic yolk surplus is absorbed. In this process, the cellular maturation is carried out leading to DG formation, which takes between 5 and $8 \mathrm{~d}$. With such yolk reserves, early juveniles of $O$. maya have up to $5 \mathrm{~d}$ to move to sites where they can find sufficient food resources for their development. These morphological and physiological changes of the digestive gland could be used to devise nourishing regimens for culture conditions of this octopus.

Unlike other species, Octopus maya has a relatively long digestive cycle in which the extracellular and intracellular digestion can take up to $8 \mathrm{~h}$. This suggests that $O$. maya is a species that can take advantage of ingested food in an efficient way, because transit of food in the digestive tract is slow. The efficiency of assimilation in cephalopods maintained in the laboratory oscillates between 80 and $90 \%$, suggesting that a great proportion of the ingested energy is transformed into biomass (Segawa \& Hanlon 1988, Farías et al. 2009). Although the ecological implications of this information for rearing will still have to be proven, the results obtained demonstrate that $O$. maya is an energetically efficient species, which is an advantageous characteristic for aquaculture conditions.

Acknowledgements. Thanks are given to CONACYT for scholarship no. 48221 to R. Martinez and for scholarship no. 207833 to O.H.A.P. The present study was partially financed by DGAPA-UNAM project no. IN216006-3 and CONACYTBasico 24743 to C. Rosas. The histology was performed at the Ecology Laboratory of the UMDI-UNAM. We express our thanks to 5 anonymous reviewers for critically reading our manuscript, and especially thank one of them for contributing to our understanding of the endo-lysosomal system and of the conceptual statements on cell and developmental biology. We also thank I. Mascher Gramlich for editing the English text.

\section{LITERATURE CITED}

Aguila J, Cuzon G, Pascual C, Domingues PM and others (2007) The effects of fish hydrolysate (CPSP) level on Octopus maya (Voss and Solis) diet: digestive enzyme activity, blood metabolites, and energy balance. Aquaculture 273:641-655

- Armant DR, Carson DD, Decker GL, Welply JK, Lennarz WJ (1986) Characterization of yolk platelets isolated from 
developing embryos of Arbacia punctulata. Dev Biol 113: 342-355

Arvy L (1960) Histoenzymological data on the digestive tract of Octopus vulgaris Lamarck (Cephalopoda). Ann NY Acad Sci 90:929-949

Avila-Poveda OH, Baqueiro-Cardenas ER (2009) Reproductive cycle of Strombus gigas Linnaeus 1758 (Caenogastropoda: Strombidae) from Archipelago of San Andres, Providencia and Santa Catalina, Colombia. Invertebr Reprod Dev 53:1-12

Avila-Poveda OH, Colin-Flores RF, Rosas C (2009) Gonad development during the early life of $O$. maya (Mollusca: Cephalopoda). Biol Bull 216:94-102

Bidder AM (1950) The digestive mechanism of the European squids Loligo vulgaris, Loligo forbesii, Alloteuthis media, and Alloteuthis subulata. Q J Microsc Sci 91:1-43

Bidder AM (1957) Evidence for an absorptive function in the 'liver' of Octopus vulgaris. Pubbl Staz Zool Napoli 29: 139-150

Boletzky Sv (1975) A contribution to the study of yolk absorption in the cephalopoda. Zoomorphology 80:229-246

Bondad-Reantaso MG, Mcgladdery SE, East I, Subasinghe RP (2001) Asia diagnostic guide to aquatic animal diseases. FAO Fish Tech Pap 402, Suppl 2. FAO, Rome

Bonet S, Huguet G (1985) Tècniques habituals de coloració per a seccions semifines de material inclós en glicol metacrilat (G.M.A.). Sci Gerundensis 10:23-32

Boucaud-Camou E (1968) Étude histologique et histochimique de l'appareil digestif de Sepiola atlantica d'Orbigny et Sepia officinalis L. Bull Soc Linn Normandie 9:220-243

Boucaud-Camou E (1973) Etude de l'appareil digestif de Sepia officinalis L. (Mollusque: Céphalopode). Essai d'analyse expérimentale des phénomènes digestifs. PhD dissertation, University of Caen

Boucaud-Camou E, Boucher-Rodoni R (1983) Feeding and digestion in cephalopods. In: Saleuddin ASM, Wilbur KM (eds) The Mollusca. Vol 5: Physiology, part 2. Academic Press, New York, NY, p 149-187

Boucaud-Camou E, Roper CFE (1995) Digestive enzymes in paralarval cephalopods. Bull Mar Sci 57:313-327

Boucaud-Camou E, Yim M (1980) Fine structure and function of the digestive cell of Sepia officinalis (Mollusca: Cephalopoda). J Zool 191:89-105

Boucher-Rodoni R (1976) Étude histologique du tube digestif de deux Cephalopodes Eledone cirrosa (Octopoda) et Illex illecebrosus (Teuthoidea), au cours de la digestion. Cah Biol Mar 17:254-260

Boucher-Rodoni R, Boucaud-Camou E, Mangold K (1987) Feeding and digestion. In: Boyle PR (ed) Cephalopod life cycles, Vol II. Academic Press, London, p 85-108

Briceño F (2009) Análisis de la variabilidad intraespecifica durante la fase exponencial de crecimiento de los juveniles de Octopus maya a través de los modelos de crecimiento, marcadores moleculares y balance de energía. MSc thesis, Universidad Nacional Autónoma de México

Briceño F, Mascaró M, Rosas C (2010a) Energy demand during exponential growth of Octopus maya: exploring the effect of age and weight. ICES J Mar Sci 67:1501-1508

Briceño F, Mascaró M, Rosas C (2010b) GLMM-based modelling of growth in juvenile Octopus maya siblings: Does growth depend on initial size? ICES J Mar Sci 67: 1509-1516

Budelmann BU, Schipp R, Boletzky Sv (1997) Cephalopoda. In: Harrison FW, Kohn AJ (eds) Microscopic anatomy of invertebrates. Vol 6A: Mollusca II. Wiley-Liss, New York, NY, p 119-414

Bustamante P (1998) Etude des processus de bioaccumulation et de détoxication d'éléments traces (métaux lourds et terres rares) chez les mollusques céphalopodes et bivalves pectinidés. Implication de leur biodisponibilité pour le transfert vers les prédateurs. $\mathrm{PhD}$ thesis, University of La Rochelle

Crossmon G (1937) A modification of Mallory's connective tissue stain with a discussion of principles involved. Anat Rec 69:33-38

Fagotto F (1990a) Yolk degradation in tick eggs. I. Occurence of a cathepsin L-like acid proteinase in yolk spheres. Arch Insect Biochem Physiol 14:217-235

Fagotto F (1990b) Yolk degradation in tick eggs. II. Evidence that cathepsin L-like proteinase is stored as a latent, acidactivatable proenzyme. Arch Insect Biochem Physiol 14: $237-252$

$>$ Fagotto F (1991) Yolk degradation in tick eggs. III. Developmentally regulated acidification of the yolk spheres. Dev Growth Differ 33:57-66

Fagotto F, Maxfield FR (1994) Changes in yolk platelet pH during Xenopus laevis development correlate with yolk utilization. A quantitative confocal microscopy study. J Cell Sci 107:3325-3337

- Farías A, Uriarte I, Hernández J, Pino S and others (2009) How size relates to oxygen consumption, ammonia excretion, and ingestion rates in cold (Enteroctopus megalocyathus) and tropical (Octopus maya) octopus species. Mar Biol 156:1547-1558

Gotelli NJ, Ellison AM (2004) A primer of ecological statistics. Sinauer Associates, Sunderland, MA

Gray P (1954) The Microtomist's formulary and guide. The Blakiston Company, New York, NY

Herrera M, Hachero-Cruzado I, Naranjo A, Mancera JM (2010) Organogenesis and histological development of the wedge sole Dicologoglossa cuneata M. larva with special reference to the digestive system. Rev Fish Biol Fish 20: 489-497

Lee R (1991) Lipoproteins from the hemolymph and ovaries of marine invertebrates. Adv Comp Environ Physiol 7:187-207

Lemaire J, Richard A, Decleir W (1977) Le foie embryonnaire de Sepia officinalis L. (Mollusque Céphalopode). I. Organogenese. Haliotis 6:287-296

Leporati SC, Pecl GT, Semmens JM (2007) Cephalopod hatchling growth: the effects of initial size and seasonal temperatures. Mar Biol 151:1375-1383

Lopez-Ripoll E (2010) Descripción del desarrollo y el efecto de la alimentación en la estructura de la glándula digestiva de juveniles tempranos de Octopus maya (Mollusca: Cephalopoda) Voss y Solís-Ramírez, 1966. BSc thesis, Jorge Tadeo Lozano University, Santa Marta

Mangold KM, Young RE (1998) The systematic value of the digestive organs. In: Voss NA, Vecchione M, Toll RB, Sweeney MJ (eds) Systematics and biogeography of cephalopods. Smithson Contrib Zool 586, Vol I, p 21-30

> Mather JA, Anderson RC (2007) Ethics and invertebrates: a cephalopod perspective. Dis Aquat Org 75:119-129

Matozzo V, Gagné F, Marin MG, Ricciardi F, Blaise C (2008) Vitellogenin as a biomarker of exposure to estrogenic compounds in aquatic invertebrates: a review. Environ Int 34:531-545

Mayhew TM (1979) Basic stereological relationships for quantitative microscopical anatomy: a simple systematic approach. J Anat 129:95-105

Medina M, Vallejo CG (1989) The maternal origin of acid hydrolases in Drosophila and their relation with yolk degradation. Dev Growth Differ 31:241-247

> Moguel C, Mascaró M, Avila-Poveda OH, Caamal-Monsreal C, Sanchez A, Pascual C, Rosas C (2010) Morphological, 
physiological, and behavioral changes during post-hatching development of Octopus maya (Mollusca: Cephalopoda) with special focus on the digestive system. Aquat Biol 9: $35-48$

Moltschaniwskyj NA, Hall K, Lipinski MR, Marian JEAR and others (2007) Ethical and welfare considerations when using cephalopods as experimental animals. Rev Fish Biol Fish 17:455-476

Morishita T (1974) Participation in digestion by the proteolytic enzymes of the posterior salivary gland in octopus. IV. Purification and some properties of proteolytic enzymes from the digestive juice. Bull Jpn Soc Sci Fish 40: 927-936

Morishita T, Ueno R, Takahashi T (1974) Participation in digestion by the proteolytic enzymes of the posterior salivary gland in octopus. I. Confirmation of the existence of protein digestive enzymes in the posterior salivary gland. Bull Jpn Soc Sci Fish 40:595-600

Morishita T, Ueno R, Takahashi T (1979) Participation in digestion by the proteolytic enzymes of the posterior salivary gland in octopus. V. Examination for finding protein digestive enzymes in the posterior salivary gland. Bull Jpn Soc Sci Fish 45:177-180

Morote E, Rodríguez M, Mancera JM, Moyano FJ, Muñoz JL (2005) Las enzimas digestivas como indicadores del estado nutricional en paralarvas de pulpo Octopus vulgaris Cuvier, 1797. Bol Inst Esp Oceanogr 21:177-186

Perrin MA (2004) Etude expérimentale des capacités digestives chez la seiche, Sepia officinalis L. (Mollusque, Céphalopode): impact de l'alimentation, indice de condition nutritionnelle et formulation d'un aliment artificiel. $\mathrm{PhD}$ thesis. University of Caen

Perrin A, Le Bihan E, Koueta N (2004) Experimental study of enriched frozen diet on digestive enzymes and growth of juvenile cuttlefish Sepia officinalis (Mollusca Cephalopoda). J Exp Mar Biol Ecol 311:267-285

Portmann A, Bidder AM (1928) Yolk absorption in Loligo and the function of the embryonic liver and pancreas. Q J Microsc Sci 72:301-324

Quintana D, Rosas C, Moreno-Villegas E (2010) Relationship between nutritional and rearing parameters of Octopus maya juveniles fed with different ratios of crab paste. Aquac Nutr doi:10.1111/j.1365-2095.2010.00772.x

Roper CFE, Sweeney MJ (1983) Techniques for fixation, preservation, and curation of cephalopods. Mem Mus Victoria 44:29-47

Rosas C, Cazares-Simental RJ, Caamal-Monsreal C, AvilaPoveda $\mathrm{OH}$ and others (2007). Adaptaciones morfológicas y digestivas durante los primeros días de vida de los juveniles del pulpo de costa Octopus maya (Voss y Solis). XIII congreso bienal, AMENA 'Asociación Mexicana de Especialistas en Nutrición Animal,' 23-26 October 2007, Veracruz, Mexico

Editorial responsibility: Hans Heinrich Janssen, Oldendorf/Luhe, Germany
Rosas C, Tut J, Baeza J, Sánchez A and others (2008) Effect of type of binder on growth, digestibility and energetic balance of Octopus maya. Aquaculture 275:291-297

Sastry KV, Singh SP, Tomar BS (2004) Cell and development biology. Rastogi Publications, New Delhi

Segawa S, Hanlon RT (1988) Oxygen consumption and ammonia excretion rates in Octopus maya, Loligo forbesi and Lolliguncula brevis (Mollusca: Cephalopoda). Mar Behav Physiol 13:389-400

Semmens JM (2002) Changes in the digestive gland of the loliginid squid Sepioteuthis lessoniana (Lesson 1830) associated with feeding. J Exp Mar Biol Ecol 274:19-39

> Semmens JM, Moltschaniwskyj NA, Alexander CG (1995) Effect of feeding on the structure of the digestive gland of the tropical sepioid Idiosepius pygmaeus. J Mar Biol Assoc UK 75:885-897

Solorzano Y, Viana MT, López LM, Correa JG, True CC, Rosas C (2009) Response of newly hatched Octopus bimaculoides fed enriched Artemia salina: growth performance, ontogeny of the digestive enzyme and tissue amino acid content. Aquaculture 289:84-90

Swift K, Johnston D, Moltschaniwskyj N (2005) The digestive gland of the Southern Dumpling Squid (Euprymna tasmanica): structure and function. J Exp Mar Biol Ecol 315: $177-186$

Umezawa H (1982) Low-molecular-weight enzyme inhibitors of microbial origin. Annu Rev Microbiol 36:75-99

Van Meel E, Klumperman J (2008) Imaging and imagination: understanding the endo-lysosomal system. Histochem Cell Biol 129:253-266

Vecchione M (1987) Juvenile ecology. In: Boyle PR (ed) Cephalopod life cycle. Vol II: Comparative reviews. Academic Press, London, p 61-84

Vecchione M, Hand VA (1989) Digestive-gland histology in paralarval squids (Cephalopoda, Loliginidae). Fish Bull 87:995-1000

Vidal EAG, Roberts MJ, Martins RS (2005) Yolk utilization, metabolism and growth in reared Loligo vulgaris reynaudii paralarvae. Aquat Living Resour 18:385-393

Westermann B, Schipp R (1998a) Morphology and histology of the digestive tract of Nautilus pompilius and Nautilus macromphalus (Cephalopoda, Tetrabranchiata). Zoomorphology 117:237-245

Westermann B, Schipp R (1998b) Cytological and enzymehistochemical investigations on the digestive organs of Nautilus pompilius (Cephalopoda, Tetrabranchiata). Cell Tissue Res 293:327-336

Yim M, Boucaud-Camou E (1980) Etude cytologique du développement post-embryonnaire de la glande digestive de Sepia officinalis L. Mollusque Céphalopode. Arch Anat Microsc Morphol Exp 69:59-79

> Yokota Y, Kato KH (1988) Degradation of yolk proteins in sea urchin eggs and embryos. Cell Differ 23:191-200

Submitted: April 26, 2010; Accepted: October 27, 2010

Proofs received from author(s): January 21, 2011 